\title{
ОБЕСПЕЧЕНИЕ ПРОДОВОЛЬСТВЕННОЙ БЕЗОПАСНОСТИ - ЗДОРОВАЯ НАЦИЯ
}

В условиях формирования социально-рыночного развития происходит переосмысление устоявшихся понятий в науке, изменение сложившихся суждений и вопрос обеспечения продовольствием населения страны становится задачей продовольственной безопасности, а не решением продовольственной проблемы. В статье рассмотрено сущностное различие таких понятий, как продовольственная безопасность и продовольственная проблема. Именно обеспечение продовольственной безопасности определяет принципиально новый подход к здоровью населения, прежде всего как к важнейшему экономическому ресурсу общества. Здоровье населения приобретает не только статус социальной ценности, но и способствует обеспечению национальной безопасности страны.

В статье исследована дифференциация уровней здоровья и выделен уровень общественного здоровья как экономической составляющей развития стран. Исходя из того, что проблема здоровья населения определяется в контексте экономического развития страны, проанализировано здоровье украинского населения за период 19902013 гг.

На основе цивилизационной концепции типов общественного здоровья определен тип здоровья, присущий современной Украине. Основная причина смерти и инвалидизации населения Украины - хронические неинфекционные заболевания (ХНИЗ). Медицина, ставя своей задачей достижение здоровья, занимается болезнью, т.е. увеличивается объём знаний о болезнях, лечебно-диагностических методах, и при этом не уделяется достаточного внимания путям достижения здоровья. Именно поэтому современная система борьбы с ХНИЗ основана на многочисленных концепциях факторов риска здоровья. Среди факторов, формирующих здоровье человека, особенно значительна роль питания, что, прежде всего, зависит от количества и качества продовольствия.

Ключевые слова: продовольственная безопасность, общественное здоровье, типы общественного здоровья, факторы риска здоровья.

\section{1. ВВЕДЕНИЕ}

История развития человеческой цивилизации свидетельствует о том, что продовольственная проблема существует с рождения человечества. В настоящее время вопрос обеспечения продовольствием может быть рассмотрен в двух ракурсах. В первом случае - как нехватка продовольствия (в целом или его отдельных видов) при недостаточном развитии производительных сил в аграрном секторе или отдельных его звеньях, при неблагоприятных погодных условиях (засуха, наводнение, град и т.д.) или губительных социально-экономических

\footnotetext{
${ }^{1}$ Кундеева Галина, кандидат экономических наук, доцент, докторант кафедры менеджмента Национального университента пищевых технологий, Киев, ул. Владимирская 68, e-mail: g_a_k@ukr.net
} 
событиях (война, восстания и др.) - продовольственная проблема в узком смысле. Во втором - как комплекс технико-экономических, социально-демографических, политических проблем производства, распределения, обмена, потребления продуктов питания, недостаток которых приводит к недоеданию, голоду, эпидемиям и социально-политической нестабильности - продовольственная проблема в широком смысле. Но решение продовольственной проблемы и в узком, и в широком смыслах - это прежде всего обеспечение реальной доступности продовольствия и ликвидация голода.

В научных исследованиях последних десятилетий активно используется термин «продовольственная безопасность», который был официально введен в международную практику после зернового кризиса 1972-1973 годов. В декабре 1974 г. Генеральной Ассамблеей ООН была принята Всеобщая декларация о ликвидации голода и недоедания. В данном документе определено, что благосостояние народов мира в значительной степени зависит от установления системы всемирной продовольственной безопасности, которая обеспечивает наличие продовольствия и разумные цены на него в любое время независимо от периодических колебаний и изменения погодных условий, а также от политического и экономического давления ${ }^{2}$ В декларации сделан упор на физическую и экономическую доступность продовольствия как условия решения продовольственной безопасности, но эти же условия необходимы и для решения продовольственной проблемы. В апреле 1983 года Комитет по продовольственной безопасности ФАО определил конечную цель продовольственной безопасности, которая заключается в обеспечении каждого человека в любое время возможностью найти и купить необходимые продукты питания ${ }^{3}$. А это, на наш взгляд, не что иное, как решение продовольственной проблемы - обеспечение доступности продовольствия.

В ноябре 1996 г. на Всемирном продовольственном саммите суть продовольственной безопасности была качественно дополнена: «лишь в случае, когда каждый человек в любое время может получить в достаточном количестве безопасное и питательное продовольствие для удовлетворения своих потребностей в питании для активной и здоровой жизни, можно говорить о продовольственной безопасности» ${ }^{4}$. Впервые сделан акцент на качестве продовольствия - подчеркнута его безопасность и питательность, а также четко очерчена более глубокая цель активная и здоровая жизнь человека. По нашему мнению, именно эти уточнения становятся основными в различиях сути продовольственной проблемы и продовольственной безопасности.

В Декларации, принятой Всемирным саммитом по продовольственной безопасности (2009 г.) определение продовольственной безопасности стало еще

\footnotetext{
${ }^{2}$ Всеобщая декларация о ликвидации голода и недоедания 1974 [Електронный ресурс] Режим доступа: http://www.un.org/ru/documents/decl_conv/declarations/hunger.shtml

${ }^{3}$ Комитет по всемирной продовольственной безопасности (CFS 83/4):

Доклад Генерального директора о всемирной продовольственной безопасности:

Переоценка концепций и подходов.

${ }^{4}$ Римська Декларація про всесвітню продовольчу безпеку і Пландій Всесвітньої зустрічі на вищому рівні з проблем продовольства, Рим,13 листопада 1996 р. [Електронний ресурс] / Продовольча ісільськогосподарська організація Об'єднаних Націй. Режим доступу : http://www.rau.su/observer/N3-4_97/019.htm.
} 
более содержательным. В документе указано, что продовольственная безопасность существует, если все люди всегда имеют физический, социальный и экономический доступ к достаточному количеству безопасного и питательного продовольствия для удовлетворения своих диетических потребностей и пищевых предпочтений для ведения активного и здорового образа жизни ${ }^{5}$. В данном определении выделена социальная доступность продовольствия, что, на наш взгляд, подчеркивает не только его экономическую, но и социальную значимость. Дополнение определения продовольственной безопасности такими целями, как удовлетворение диетических потребностей и пищевых предпочтений свидетельствует о диетической, лечебной значимости питания, а именно, свойстве продовольствия не только поддерживать, но и обеспечивать здоровую жизнь. В тоже время пищевые потребности формируют спрос потребителя на продовольственные продукты и, соответственно, структуру производства продовольствия и конъюнктуру продовольственного рынка.

\section{2. ГЕНЕЗИС КАТЕГОРИИ «ПРОДОВОЛЬСТВЕННАЯ}

\section{БЕЗОПАСНОСТЬ» В ЗАКОНОДАТЕЛЬНОМ ПОЛЕ УКРАИНЫ}

Анализ последних научных публикаций и законодательных документов Украины указывает на отсутствие понимания важности глобального вопроса здоровья в контексте продовольственной безопасности. Так, в Законе Украины «О государственной поддержке сельского хозяйства Украины» (2004 год) сказано: «продовольственная безопасность - это защищенность жизненных интересов человека, которая выражается в обеспечении государством беспрепятственного экономического доступа человека к продуктам питания с целью поддержания его обычной жизненной деятельности» ${ }^{6}$. Но в данном документе речь не идет об обеспечении здоровой активной жизни, стоит вопрос только в обеспечении обычной жизненной деятельности. А что такое обычная жизненная деятельность? Синонимом слова «обычный» может быть слово «простой». В свою очередь, простое обеспечение жизнедеятельности можно рассматривать как нормальное функционирование человеческого организма в состоянии покоя или деятельность человека по обслуживанию самого себя. С экономической точки зрения именно трудовая деятельность обеспечивает рост экономики и богатства страны. Таким образом, продовольственная безопасность должна обеспечивать не только простую обычную жизненную деятельность, но и активную трудовую. Именно такой подход не противоречит теории человеческого капитала, где здоровье человека рассматривается как один из его главных компонентов.

В 2011году Верховным Советом Украины был принят Проект закона, в котором продовольственная безопасность рассмотрена как социальноэкономическое и экологическое состояние, при котором все социальные и демографические группы населения стабильно и гарантированно обеспечены безопасным и качественным продовольствием в достаточном количестве и ассортименте, необходимом для физического и социального развития личности и

\footnotetext{
5 Декларация Всемирного саммита по продовольственной безопасности, WSFS 2009/2, http://www.un.org/ru/documents/decl_conv/declarations/pdf/summit2009_declaration.pdf ${ }^{6}$ Про державну підтримку сільського господарства України ( Відомості Верховної Ради України (ВВР), 2004, N 49, ст.527
} 
обеспечивающим здоровье населения Украины. В документе четко определена цель - обеспечение здоровья украинцев, однако данный проект закона не был ветирован президентом Украины ${ }^{7}$.

В декабре 2013 года в Проекте указа Президента Украины «Об основах обеспечения продовольственной безопасности Украины» продовольственная безопасность определена как защищенность жизненно важных интересов человека в обеспечении стабильного беспрепятственного физического и экономического доступа к безопасному и качественному продовольствию в необходимом количестве и ассортименте с целью поддержания его обычной жизнедеятельности. Данный документ не расширяет цель продовольственной безопасности до уровня здоровой, активной жизни. Необходимо отметить, что этот проект указа не был принят в связи с изменениями политической ситуации в стране ${ }^{8}$.

\section{3. ЗДОРОВЬЕ КАК ЦЕЛЬ ПРОДОВОЛЬСТВЕННОЙ БЕЗОПАСНОСТИ}

Проведенный анализ трансформации продовольственной проблемы (необходимости продовольственного обеспечения) в продовольственную безопасность определяет их главное отличие: цель продовольственного обеспечения - ликвидация голода для выживания человечества, a продовольственная безопасность - гарантия такого уровня здоровья всем индивидуумам, который обеспечивает им активную продолжительную жизнедеятельность. Именно поэтому целью нашей работы является изучение содержания термина «здоровье» и факторов, которые на него влияют.

Анализ научных трудов по вопросам понятия «здоровье человека» свидетельствует о том, что последнему уделялось внимание не только в специальных областях науки (медицина), а и в таких научных сферах, как философия, социология и экономика. В современных условиях построения в Украине социально-ориентированной экономики, прежде всего необходимо повышение значимости здоровья как основы общественного богатства. Активное долголетие должно быть главным критерием социального прогресса и гуманизации общества, поэтому нами исследовано содержание категории «здоровье»; рассмотрено дифференциацию уровней здоровья и типов общественного здоровья; исследовано влияние факторов на здоровье человека.

Всемирная организация здравоохранения (ВО3) определяет здоровье как состояние полного физического, духовного и социального благополучия, а не только отсутствие болезней и физических дефектов ${ }^{9}$. Проведенный анализ научной литературы свидетельствует о том, что здоровье как предмет исследования занимало умы философов древности, рассматривающих здоровье как базисную жизненную потребность индивида, основное условие жизнедеятельности

\footnotetext{
${ }^{7}$ Проект Закона “О продовольственной безопасности Украины”.[Электронный ресурс]. Режим доступа: http://www.unian.net.

${ }^{8}$ Проект указа Президента Украины «Об основах обеспечения продовольственной безопасности Украины»: http://minprom.ua/digest/142488.html

${ }^{9}$ Устав (конституция) Всемирной организации здравоохранения (Нью-Йорк, 22 июля 1946 года). [Электронный ресурс]. - Режим доступа: - http://www.doctorate.ru/ustav-vsemirnojorganizacii-zdravooxraneniya/
} 
человека ${ }^{10}$. Многообразие определений здоровья позволяет выделить его обобщающие признаки:

- нормальная функция организма на всех уровнях его организации, нормальное течение физических и биохимических процессов, способствующих индивидуальному выживанию и воспроизводству;

- динамическое равновесие организма и его функций по отношению к факторам окружающей среды;

- способность к полноценному выполнению основных функций, участие в социальной деятельности и общественнополезном труде;

- способность организма приспосабливаться к постоянно меняющимся условиям существования в окружающей среде, поддерживать постоянство внутренней среды организма, обеспечивая нормальную и разностороннюю жизнедеятельность;

- отсутствие болезни, болезненных состояний либо болезненных изменений;

- полное физическое, духовное, умственное и социальное благополучие, гармоническое развитие физических и духовных сил организма, принцип его единства, саморегуляции и гармонического взаимодействия всех органов ${ }^{11}$.

Многие ученые разграничивают «индивидуальное» и «общественное» здоровье (здоровье населения, нации). Индивидуальное здоровье характеризует состояние здоровья конкретного человека - индивидуума. Оно обусловленно преимущественно эндогенными факторами, и зависит от множества случайных внешних процессов и явлений ${ }^{12}$. Анализ научной литературы по вопросам индивидуальногоздоровья позволяет выделить следующие составляющие:

- биологическая, рассматривающая здоровье как категорию функционального состояния организма, основу которого составляют развитие органов и систем органов, и обеспечивающая адаптационные реакции (физическое здоровье);

- социальная, представляющая здоровье как условие эффективного участия в общественной жизни, основу которого определяет система ценностей, установок и мотивов поведения индивидуума в обществе (нравственное здоровье);

- смешанная или биосоциальная, рассматривающая здоровье как общее хорошее самочувствие личности, основу которого составляет состояние общего душевного комфорта, и обеспечивающая адекватную поведенческую реакцию (психическое здоровье) ${ }^{13}$.

Параметры индивидуального здоровья не могут служить основанием для принятия политических, социальных и экономических решений, направленных на оптимизацию условий жизни населения на макроуровне. При принятии данных решений необходимо учитывать качество здоровья всего населения страны, потому используется термин «общественное здоровье» или «здоровье нации, популяции». Суть данного термина состоит в совокупности свойств человеческой общности,

\footnotetext{
${ }^{10}$ Ларионова И.С. Философия здоровья - М.:Гардарики, 2007. - 224c.

${ }^{11}$ Калью П.И. Сущностная характеристика понятия «здоровье» и некоторые вопросы перестройки здравоохранения: обзорная информация.- М., 1988. С. 33-35.

${ }^{12}$ Здоровье и здравоохранение в гендерном измерении / под. общ. ред. Н.М. Римашевской. М.: Социальный проект, 2007.

${ }^{13}$ Никифоров Г.С. Здоровье как системное понятие. Психология здоровья / Под ред. Г.С. Никифорова. - СПб.: К, 1998.
} 
проживающей на той или иной территории, позволяющей не только осуществлять социальные функции, но и воспроизводить и воспитывать новые здоровые поколения. Общественное здоровье зависит от индивидуального здоровья каждого человека, но при этом не сводится к совокупности показателей здоровья отдельных людей. Это качественно более высокий уровень, рассматривающий общество как единый социально-экономический организм.

Таким образом, если индивидуальное здоровье характеризует состояние здоровья конкретного человека - индивидуума, то общественное здоровье жизнеспособность всего общества как социального организма и его возможности непрерывного духовного роста и социально-экономического развития. В тоже время в условиях формирования социально-рыночных механизмов здоровье населения приобретает не только статус социальной ценности, но и важнейшего экономического ресурса общества. Общественное здоровье становиться социальноэкономическим ресурсом, способствующим обеспечению национальной безопасности страны.

Необходимо обратить внимание на тот факт, что сегодняшнее состояния здоровья людей накладывает огромный отпечаток не только на их завтрашнее здоровье, но и обладает выраженным наследственным эффектом, предопределяя здоровье будущих поколений. Причем ухудшение здоровья населения оказывает отрицательный мультипликативный эффект на будущие поколения, и тем самым негативно влияет на перспективы развития национальной экономики в будущем.

В свою очередь, цивилизационное развитие оказывает влияние здоровье населения. Б.Б. Прохоровым выделено пять типов общественного здоровья, которые существенно варьируются во времени и пространстве ${ }^{14}$.

Таблица 1. Классификация типов общественного здоров'я.

\begin{tabular}{|c|c|}
\hline Тип здоровья & Характеристика типов общественного здоровья \\
\hline Примитивный & $\begin{array}{l}\text { Простое выживание человеческих общностей под постоянной } \\
\text { угрозой насильственной смерти. Средняя продолжительность } \\
\text { жизни населения - в пределах } 20-22 \text { лет. Младенческая } \\
\text { смертность }-50 \text { случаев и более на } 100 \text { новорожденных. }\end{array}$ \\
\hline Постпри & $\begin{array}{l}\text { Короткая продолжительность жизни большинства населения, } \\
\text { с высокой вероятностью преждевременной смерти от } \\
\text { периодически возникавших эпидемий острозаразных болезней } \\
\text { и голода. Величина средней продолжительности жизни - в } \\
\text { пределах от } 20 \text { до } 30 \text { лет. Младенческая смертность }-200 \\
\text { случаев и более на } 1000 \text { новорожденных. }\end{array}$ \\
\hline Квазимодерный & 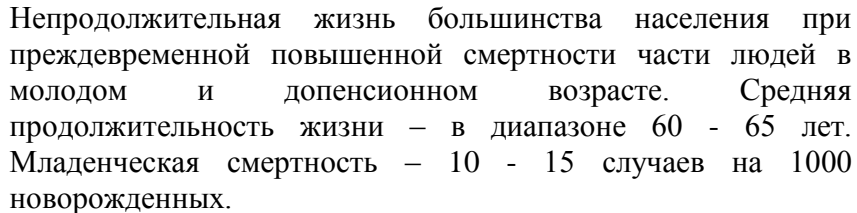 \\
\hline
\end{tabular}

\footnotetext{
${ }^{14}$ Общественное здоровье и экономика / Б.Б. Прохоров [и др.].- М.: МАКС Пресс, 2007. - 292
} c. 


\begin{tabular}{|l|l|}
\hline Модерный & $\begin{array}{l}\text { Продолжительная жизнь большинства населения с надежной } \\
\text { и эффективной работоспособностью и здоровой старостью. } \\
\text { Продолжительность жизни - в пределах } 75-80 \text { лет, а } \\
\text { младенческая смертность не превышает } 6 \text { - } 8 \text { случаев на } 1000 \\
\text { новорожденных. }\end{array}$ \\
\hline Постмодерный & $\begin{array}{l}\text { Для этого этапа характерны резкое снижение числа больных } \\
\text { всеми видами заболеваний, успешное лечение ныне } \\
\text { неизлечимых недугов, полноценная радостная жизнь } \\
\text { подавляющего большинства населения. Продолжительность } \\
\text { жизни населения будет не ниже } 82-85 \text { лет, а младенческая } \\
\text { смертность не превысит } 5 \text { случаев на } 1000 \text { новорожденных. }\end{array}$ \\
\hline
\end{tabular}

Составлено автором на основе работ Б.Б. Прохорова ${ }^{15}$ и Флоринской Ю.Ф. ${ }^{16}$

\section{4. АНАЛИЗ ТИПА ОБЩЕСТВЕННОГО ЗДОРОВЬЯ УКРАИНЫ}

Для определения типа общественного здоровья Украины нами проведен анализ демографических изменений за 1990-2013 гг. Анализ естественного прироста/убыли населения в Украине свидетельствует о затяжной тенденции демографического спада населения страны начиная с 1991 года (табл.2). Максимальнаяубыль населения - на уровне 7,6 человек на 1000 населения прослеживается в 2001-2002 гг. и в 2005 году. Минимальная естественная убыль населения - в 2012 году на уровне 3,1 человека на 1000 населения (табл.2).

Существование такой тенденции мы объясняем наличием определенного временного лага между действиями экономических и политических факторов в Украине и среднестатистической продолжительностью жизни.

Анализируя динамику смертности детей за 1990-2013 гг., мы прослеживаем существование двух участков значительного роста детской смертности: первый участок - увеличение смертности с 12,8 детей на 1000 новорожденных в 1990 году до 14,7 детей - в 1995 году; второй участок - рост смертности до 11 детей на 1000 новорожденных в 2007 году. Если первый период можно связать с трансформационным кризисом (периодом перестройки в Украине), который ухудшил имущественное положение многих украинцев, то рост в 2007 году (период экономического подъёма в стране) объяснить только экономическими факторами невозможно (рис.1). Может быть, это связано с тем, что стали рожать женщины, рождение и первые года жизни которых приходятся на 1986 год - год аварии на Чернобыльской АЭС.

\footnotetext{
${ }^{15}$ Там же.

${ }^{16}$ Флоринская Ю.Ф. Качество жизни и здоровье населения. [Электронный ресурс]. - Режим доступа: https://bio.1september.ru/article.php?ID=200400504.
} 
Таблица 2. Динамика естественного увеличения /уменьшения населения Украины (на 1000 наличного населения).

\begin{tabular}{|c|c|c|c|c|c|c|c|c|c|c|c|c|c|c|c|c|c|c|c|c|c|c|c|c|}
\hline Года & § & $\bar{\Omega}$ & $\sigma$ & $\hat{\sigma}$ & ন & $\stackrel{2}{2}$ & 2 & ळ & $\stackrel{\infty}{2}$ & Әे & 豙 & ठ্ঠ & 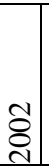 & 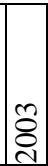 & 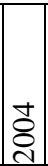 & $\mid \begin{array}{l}2 \\
0 \\
\tilde{d}\end{array}$ & $\mid$ & ¿્o & & & $D$ & & $\frac{v}{2}$ & \\
\hline \begin{tabular}{|l} 
Количество \\
новорожденных \\
на 1000 \\
наличного \\
населения \\
\end{tabular} & $\begin{array}{l}0 \\
\text { I }\end{array}$ & $\overrightarrow{\mathrm{C}}$ & $\stackrel{\nabla}{\Xi}$ & $\ddot{\circ}$ & $\stackrel{0}{0}$ & $\stackrel{0}{0}$ & $\frac{n}{\sigma}$ & $\underset{\infty}{\infty}$ & $\underset{\infty}{+}$ & $\stackrel{\infty}{\sim}$ & $\stackrel{\infty}{\sim}$ & $\stackrel{2}{2}$ & $\vec{\infty}$ & $\stackrel{n}{\infty}$ & $a$ & $a$ & {$\left[\begin{array}{l}\infty \\
\sigma \\
\sigma\end{array}\right]$} & 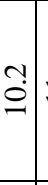 & $=$ & & $\stackrel{\infty}{\stackrel{\infty}{0}=}=$ & & & 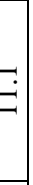 \\
\hline $\begin{array}{l}\text { Количество } \\
\text { умерших на } \\
1000 \text { наличного } \\
\text { населения }\end{array}$ & $\overline{\mathrm{I}}$ & $\hat{\jmath}$ & $\stackrel{\nabla}{\ddot{\nu}}$ & $\begin{array}{l}\sim \\
\pm\end{array}$ & $\stackrel{\Im}{ \pm}$ & $\stackrel{\nabla}{\stackrel{\Delta}{ }}$ & ป઼ & $\stackrel{g}{ \pm}$ & $\stackrel{ナ}{ \pm}$ & $\stackrel{g}{ \pm}$ & $\begin{array}{l}\Delta \\
\end{array}$ & ?ִ & in & 0 & 0 & $\mid \begin{array}{l}0 \\
\dot{0} \\
-\end{array}$ & $\left(\begin{array}{c}r \\
6 \\
-\end{array}\right.$ & $\stackrel{+}{\circ}$ & $\begin{array}{l}3 \\
\stackrel{n}{0} \\
-\end{array}$ & $\begin{array}{lll}n & \text { in } \\
n & \text { in }\end{array}$ & $\begin{array}{l}c \\
\stackrel{1}{c}\end{array}$ & & $\stackrel{?}{ \pm}$ & \\
\hline $\begin{array}{l}\text { Природный } \\
\text { прирост/убыль } \\
\text { населения }\end{array}$ & ? & $\stackrel{\infty}{\infty}$ & 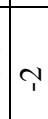 & $\stackrel{\sim}{\sim}$ & $\underset{+}{+}$ & $\underset{\sim}{\infty}$ & 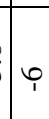 & ֶָ. & o & $\vec{T}$ & \begin{tabular}{l}
0 \\
\hdashline \\
\hdashline
\end{tabular} & \begin{tabular}{l}
0 \\
\hdashline \\
\end{tabular} & $\left|\begin{array}{l}0 \\
\hdashline \\
1\end{array}\right|$ & $\frac{n}{?}$ & 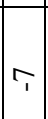 & بִ & $\left|\begin{array}{l}+ \\
\dot{\varphi} \\
1\end{array}\right|$ & ֶָ. & m? & $\begin{array}{l}y \\
+ \\
i\end{array}$ & $\begin{array}{l}\text { S } \\
+\end{array}$ & & $\vec{r}$ & $?$ \\
\hline
\end{tabular}

Составлено автором на основе данных Госкомстата

Существование такой тенденции мы объясняем наличием определенного временного лага между действиями экономических и политических факторов в Украине и среднестатистической продолжительностью жизни.

Анализируя динамику смертности детей за 1990-2013 гг., мы прослеживаем существование двух участков значительного роста детской смертности: первый участок - увеличение смертности с 12,8 детей на 1000 новорожденных в 1990 году до 14,7 детей - в 1995 году; второй участок - рост смертности до 11 детей на 1000 новорожденных в 2007 году. Если первый период можно связать с трансформационным кризисом (периодом перестройки в Украине), который ухудшил имущественное положение многих украинцев, то рост в 2007 году (период экономического подъёма в стране) объяснить только экономическими факторами невозможно (рис.1). Может быть, это связано с тем, что стали рожать женщины, рождение и первые года жизни которых приходятся на 1986 год - год аварии на Чернобыльской АЭС.

Анализируя динамику показателя детской смертности, мы можем констатировать, что в течение 2003-2013 гг. (за исключением 2007г.) для страны был присущ модерный тип общественного здоровья. Однако, необходимо отметить, что в Украине наблюдается высокий уровень заболеваемости среди детей и подростков. За период обучения в школе число здоровых детей с первого по одиннадцатый класс уменьшается в 3-4 раза ${ }^{18}$.

Рис. 1. Динамика детской смертности на1000 новорожденных в Украине за годы независимости (составлено автором на основе данных Госкомстата).

\footnotetext{
${ }^{17}$ Официальный сайт [Электронный ресурс]. - Режим доступа: http://www.ukrstat.gov.ua/

${ }^{18}$ Официальный сайт [Электронный ресурс]. - Режим доступа: http://censor.net.ua/n235806
} 
Fig.1. Dynamics ofinfant mortalityper 1000 newbornsin Ukrainesince independence(compiled by the author on the basis ofState Statistics Committee).

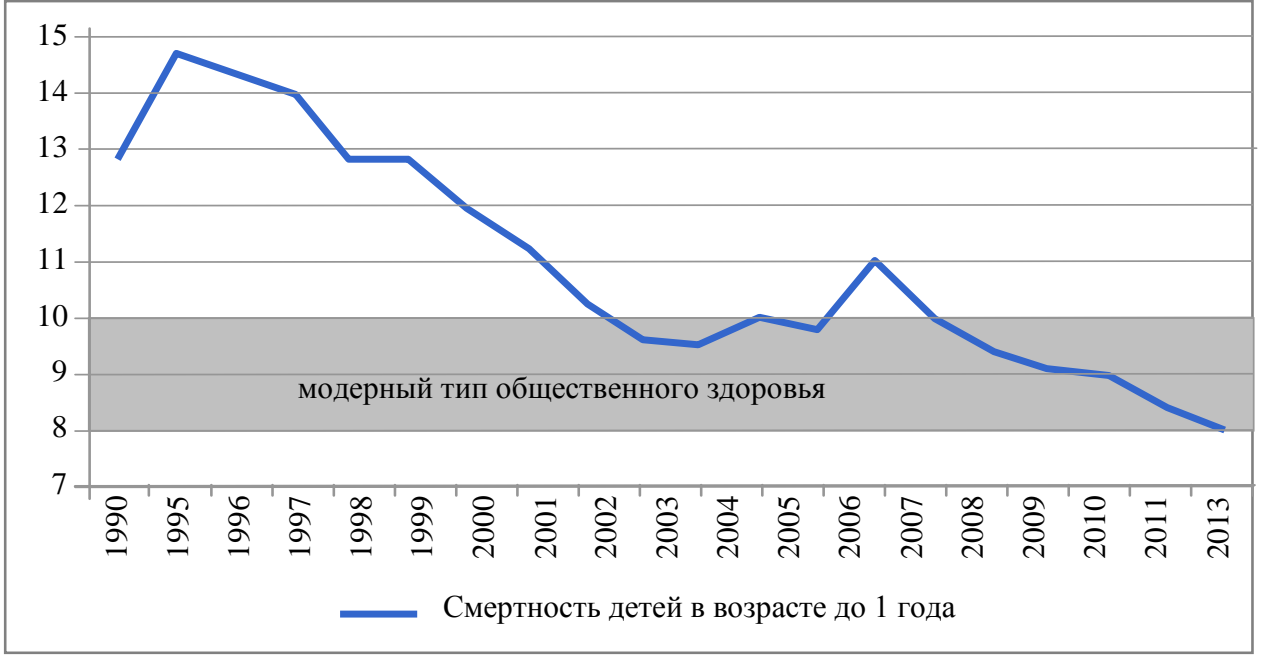

Анализ статистических данных продолжительности жизни свидетельствует о том, что в течение 1990-1991 годов средняя продолжительность жизни мужчин и женщин в Украине составляла 69,3 года. В период с 1995г. по 1996г. продолжительность жизни уменьшалась, достигнув показателя 66,9 лет, но с 1997 года наблюдается тенденция к увеличению продолжительности жизни до 71,37 лет в 2013 году. Причем средняя продолжительность жизни украинских мужчин за годы независимости составляет около 63,25 лет, а женщин - 74,15 лет (рис. 2). Анализируя данные показатели, можно констатировать, что возрастной порог смертности квазимодерного типа общественного здоровья для женщин преодолен. Он, начиная с 2009-2010 гг., превышает отметку в 75 лет. Однако ожидаемая продолжительность жизни при рождении в период с 1990 по 2012 гг. уменьшилась на один год. Этот показатель составлял в 2012 году 68,8 лет против 69,8 лет в 1990 году.

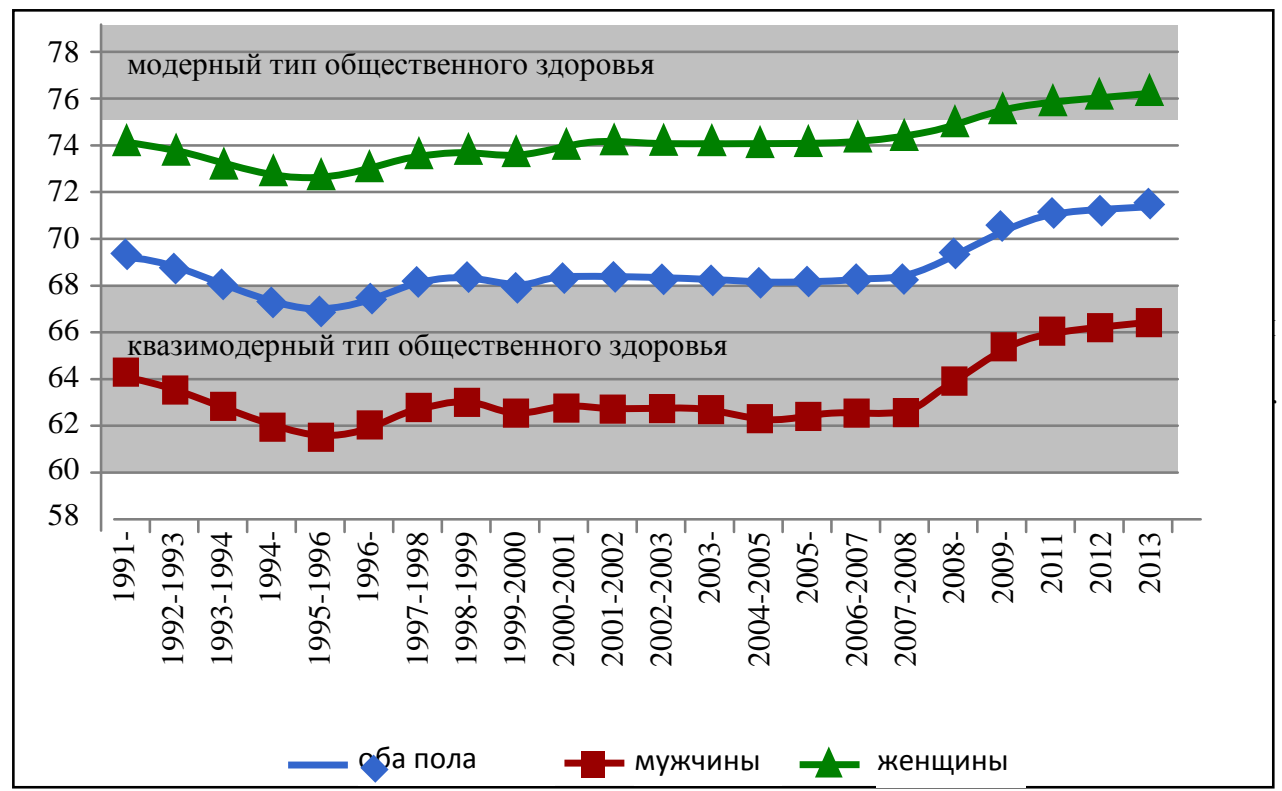


На наш взгляд, для Украины существует достаточно большая вероятность задержаться в квазимодерном типе. Это связано с тем, что «почти половина взрослого населения, преимущественно молодежь, страдает от одного или нескольких хронических заболеваний» ${ }^{19}$.

Как свидетельствуют результаты исследования основных причин высокой смертности в Украине, не уменьшается смертность среди населения трудоспособного возраста ${ }^{20}$. Эти факты дают возможность предположить, что для Украины присущ квазимодерный тип общественного здоровья.

\section{5. КОНЦЕПЦИЯ ФАКТОРОВ РИСКА ЗДОРОВЬЯ}

Проведенный анализ научных работ по проблеме борьбы с хроническими неинфекционными заболеваниями (ХНИЗ) свидетельствует о существовании многочисленных концепций факторов риска здоровья, сделана определенная структуризация факторов риска здоровья и предложены модели риска здоровья. Так Дж. Далгреном и М.Вайтгедом предложена классификация факторов, на основе которой ученые разработали модель «радуги факторов здоровья», состоящую из пяти цветов-факторов ${ }^{21}$. В центре данной модели - люди с фиксированными показателями возраста, пола и конституционные факторы, влияющие на здоровье. Все остальные цвета (слои) радуги определяют детерминанты влияния на здоровье человека. Внутренний слой представляет собой личное поведение и образ жизни (например, привычки к курению или физической активности). Следующий слой общение с друзьями, родственниками и обществом. Существенное влияние на здоровье человека оказывают условия его жизни и труда, продовольствие и доступ к основным жизненнонеобходимым товарам, а также к образованию -четвертый слой модели. Пятый, внешний слой, свидетельствует о важном значении для общего состояния здоровья таких составляющих общественного развития, как экономические, культурные и экологические условия. Данная модель подчеркивает взаимодействия между выше указанными различными слоями - отдельные составляющие образа жизни кроются в социальных и общественных условиях существования общества, а также в условиях труда, которые, в свою очередь, тесно связаны с культурой, социально-экономическими условиями и окружающей средой.

Х. Бартон и М. Грант, увеличив количество факторов до восьми, предложили модель «карта здоровья». Она расширяет модель «радуга факторов здоровья» за счет теории экосистем и принципов устойчивого развития ${ }^{22}$. Проведенный анализ научной литературы указывает на то, что наиболее цитируемой является следующая классификация факторов риска общественного здоровья: уровень и образ жизни

\footnotetext{
${ }^{19}$ Основні причини високого рівня смертності в Україні. - К.: ВЕРСО-04 - 2010. - С. 60.

${ }^{20}$ Основні причини високого рівня смертності в Україні. - К.:ВЕРСО-04 - 2010. - С.7.

${ }^{21}$ Whitehead M,Dahlgren G, Gilson L.Developing the policy response to inequities in Health: aglobal perspective / Challenging inequities in health care:from ethics to action. New York:Oxford University Press;2001:309-322c.314

${ }^{22}$ Barton H and Grant M (2006) A health map for the local human habitat,. The Journal for the Royal Society for the Promotion of Health , 126 (6). pp. 252-253. IThe publisher's URL is: http://dx.doi.org/10.1177/1466424006070466

http://eprints.uwe.ac.uk/7863/2/The_health_map_2006_JRSH_article_-_post_print.pdf
} 
населения, состояние окружающей среды, наследственность, а также уровень развития медицинской помощи. При этом влияние первого фактора на здоровье составляет более $50 \%$, влияние наследственности и экологии представляет по 15 $20 \%$, на долю медицинской помощи приходится в среднем $10-15 \%{ }^{23}$. Предложенная Лисициным Ю.П. ${ }^{24}$ группировка факторов риска здоровья представлена в таблице 3.

Таблица 3.Группировка факторов риска.

\begin{tabular}{|c|c|c|}
\hline $\begin{array}{l}\text { Категории } \\
\text { факторов риска }\end{array}$ & Примеры факторов риска & Доля, $\%$ \\
\hline Образ жизни & $\begin{array}{l}\text { Курение } \\
\text { Употребление алкоголя } \\
\text { Несбалансированное питание } \\
\text { Стрессовые ситуации (дистрессы) } \\
\text { Вредные условия труда } \\
\text { Гиподинамия } \\
\text { Низкая физическая активность } \\
\text { Потребление наркотиков, злоупотребление лекарствами } \\
\text { Напряженные семейные отношения } \\
\text { Напряженные психоэмоциональные отношения на работе } \\
\text { Низкий культурный и образовательный уровень }\end{array}$ & $50-55$ \\
\hline Внешняя среда & $\begin{array}{l}\text { Загрязнение воздуха канцерогенами и другими вредными } \\
\text { веществами } \\
\text { Загрязнение воды канцерогенами и другими вредными } \\
\text { веществами } \\
\text { Загрязнение почвы } \\
\text { Резкие смены состояния атмосферы } \\
\text { Повышенные гелиокосмические, радиационные, } \\
\text { магнитные и другие излучения }\end{array}$ & $20-25$ \\
\hline $\begin{array}{l}\text { Генетические } \\
\text { факторы }\end{array}$ & $\begin{array}{l}\text { Предрасположенность к наследственным болезням } \\
\text { Наследственная предрасположенность к тем или иным } \\
\text { заболеваниям }\end{array}$ & $15-20$ \\
\hline Здравоохранение & $\begin{array}{l}\text { Неэффективность профилактических мероприятий } \\
\text { Низкое качество и несвоевременность медицинской } \\
\text { помощи }\end{array}$ & $10-15$ \\
\hline
\end{tabular}

Среди факторов, формирующих риски здоровью человека, особенно значительна роль питания, так как именно на питание приходится $40-45 \%$. Д.Ф.Чеботарев утверждает, что питание - это практически единственное средство, пролонгирующее видовую продолжительность жизни на $25-40 \%{ }^{26}$. По мнению В. А. Тутельяна,

\footnotetext{
${ }^{23}$ Коркушко О.В., Калиновская Е.Г., Молотков В.И. Преждевременное старение человека. Киев, 1979. - 192 с.

${ }^{24}$ Лисицын Ю.П. Общественное здоровье и здравоохранение [Текст]. - М.: ГЭОТАР-Медиа, 2009. $-512 \mathrm{c}$.

25 Зубар Н.М. Основи фізіології та гігієни харчування. Підручник. - К.: Центр учбової літератури, 2010. - 336 с.

${ }^{26}$ Ковтун Т, В, Перспективы создания продуктов геродического назначения

Политематический сетевой электронный научный журнал Кубанского государственного аграрного университета. -Выпуск№ 67 / 2011http://cyberleninka.ru/article/n/perspektivysozdaniya-produktov-gerodieticheskogo-naznacheniya
} 
главным фактором, который наносит непоправимый, на несколько порядков больший урон здоровью человека, чем экологическая загрязненность и психосоциальные стрессы вместе взятые, является нарушение структуры питания ${ }^{27}$.

По данным Всемирной организации здравоохранения (ВО3), качественное питание позволяет избежать $40 \%$ заболеваний и значительно увеличить продолжительность жизни. Определена группа заболеваний, возникновение и развитие которых зависит от питания: нервные и психические расстройства; респираторные заболевания; инфекционные и паразитарные заболевания; заболевания желудочно-кишечного тракта; эндокринные нарушения; пищевые отравления.

Экспертами ВО3 было определено влияние питания на распространенность ХНИЗ и выделены заболевания, непосредственно зависящие от питания: сердечнососудистые заболевания; злокачественные новообразования; сахарный диабет; заболевания, обусловленные недостаточным (анорексия) и избыточным (ожирение) питанием. При этом следует отметить, что стоимость лечения сердечно-сосудистых заболеваний в Европе за год составляет 270 млрд $€$, а стоимость лечения онкологических заболеваний, только в Европе, превышает 59 млрдє. ${ }^{28}$

В Украине общая смертность населения и смертность по отдельным заболеваниям вдвое превышает соответствующие показатели стран Европейского Союза. Только из-за преждевременной смертности населения ежегодно теряется примерно 4 млн лет потенциальной жизни. Соответственно, объем недовыработанного национального продукта составляет от 47,9 до 89,1 млрд гривен $^{29}$. Проведенный анализ смертности от неинфекционных заболеваний (рис.3) свидетельствует о том, что $67,55 \%$ смертельных случаев приходится на смертность от сердечно-сосудистых заболеваний, на втором месте - онкологические заболевания (14,34\%).

Треть умерших - люди допенсионного возраста, и наблюдается высокий риск смертности украинцев в раннем возрасте.

\footnotetext{
${ }^{27}$ В.А. Тутельян, А.Н. Разумов, А.И. Вялков, В.И. Михайлов, К.А. Москаленко, А.Г. Одинец, В.Г. Сбежнева, В.Н. Сергеев. Научные основы здорового питания:- М.: Издательский дом «Панорама», 2010.- $816 \mathrm{c}$.

${ }^{28}$ Хорбаньчук Я.О., Юзвик А., Томасик Ц., Хорбаньчук К., Шиманская Е., Сивец Д. Функциональные продукты питания животного происхождения и их значение для здоровья людей / Птица и птицепродукты 2009. - №3 - С.15-17.

${ }^{29}$ Официальный сайт [Электронный ресурс]. - Режим доступа: http://w1.c1.rada. gov.ua/pls/zweb2/webproc4_1?pf3511=49269
} 
Рис. 1. Динамика детской смертности на1000 новорожденных в Украине за годы независимости (составлено автором на основе данных Госкомстата).

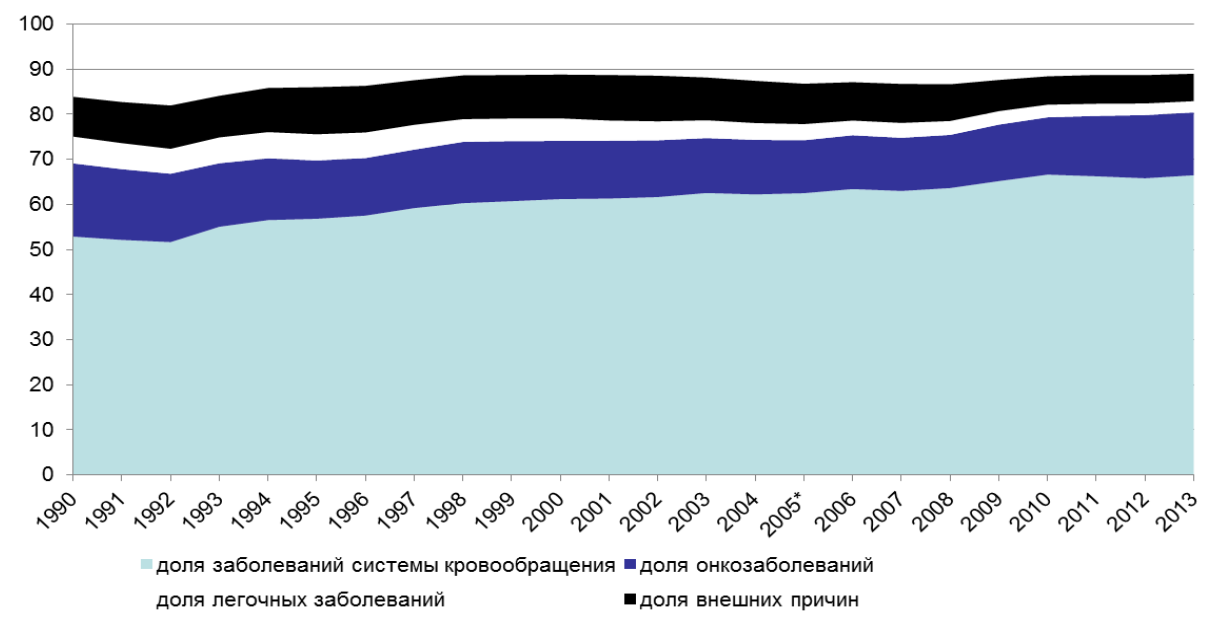

При низких доходах и постоянно растущих ценах не только на продукты питания, но и на медицинские препараты и услуги, продовольственный фактор становится одним из главных факторов физического существования украинской нации.

\section{6. ВЫВОДЫ}

Недооценка ресурсов здоровья как объекта рыночной экономики является сдерживающим фактором эффективного развития многих стран и регионов. В Украине, как и в большинстве постсоветских стран, сложилась «нездоровая» экономика - экономика, для которой здоровье как экономическая категория, не является ни объектом, ни критерием, ни целью развития данных стран. Подтверждение этому - крайне низкая продолжительность жизни людей (60-70 лет) по сравнению с генетическим потенциалом человека (120-140 лет). Мы считаем, что здоровье - больше, чем просто ресурс.

Это непосредственный производственный ресурс, так как производство всех товаров связано с расходованием жизненной энергии и здоровья в том числе, следовательно в его приумножении обязаны быть заинтересованы как государство, так и отдельные индивиды. В Украине именно здоровье должно быть основным капиталом экономики. В то же время, в учебных курсах экономической теории и микроэкономики, изучаемых в высших учебных заведениях различного уровня и разнонаправленной специализации, здоровье, как социально-экономический ресурс, не исследуется.

Системно не рассматривается и зависимость уровня заболеваемости неинфекционными болезнями украинцев от качества, структуры и режима питания. Существенное влияние продуктов питания и организации их потребления на здоровье человека превращает проблему питания в актуальную глобальную проблему человечества. Поэтому исследование рациона питания и физиологических 
норм потребления по основным продовольственным группам требуют системного исследования.

\section{ЛИТЕРАТУРА}

[1] Barton H and Grant $M$ (2006) A health map for the local human habitat,. The Journal for the Royal Society for the Promotion of Health , 126 (6). pp. 252-253. I The publisher's URL is:http://dx.doi.org/10.1177/1466424006070466

[2] Whitehead M,Dahlgren G, Gilson L. Developing the policy response to inequities in Health: a global perspective / Challenging inequities in health care:from ethics to action. New York:Oxford University Press;2001:309-322 c. 314

[3] Всеобщая декларация о ликвидации голода и недоедания [Электронный pecypc] - Режим доступа: http://www.un.org/ru/documents/decl_conv/ declarations/hunger.shtml

[4] Декларация Всемирного саммита по продовольственной безопасности,WSFS 2009/2, http://www.un.org/ru/documents/decl_conv/declarations/pdf/summit2009_de claration.pdf

[5] Здоровье и здравоохранение в гендерном измерении / под. общ. ред. Н.М. Римашевской. - М.: Социальный проект, 2007. - 204 с.

[6] Зубар Н.М. Основи фізіології та гігієни харчування. Підручник. - К.: Центр учбової літератури, 2010. - 336 с.

[7] Калью П.И. Сущностная характеристика понятия «здоровье» и некоторые вопросы перестройки здравоохранения: обзорная информация.- М., 1988. $-158 \mathrm{c}$.

[8] Ковтун Т. В. Перспективы создания продуктовгеродического назначения Политематический сетевой электронный научный журнал Кубанского государственного аграрного университетаВыпуск№ 67 / $2011 \mathrm{http} / / /$ cyberleninka.ru/article/n/perspektivy-sozdaniya-produktovgerodieticheskogo-naznacheniya

[9] Комитет по всемирной продовольственной безопасности (CFS 83/4): Доклад Генерального директора о всемирной продовольственной безопасности: Переоценка концепций и подходов http://www.fao.org/docrep/meeting/026/MD776R.pdf

[10] Коркушко О.В., Калиновская Е.Г., Молотков В.И. Преждевременное старение человека. - Киев, 1979. - 192 с.

[11] Ларионова И.С. Философия здоровья - М.:Гардарики, 2007. - 224c.

[12]Лисицын Ю.П. Общественное здоровье и здравоохранение [Текст]. М.: ГЭОТАР-Медиа, 2009. - 512 с.

[13]Никифоров Г.С. Здоровье как системное понятие. Психология здоровья / Под ред. Г.С. Никифорова. - СПб.: К, 1998. - 235 с.

[14] Основні причини високого рівня смертності в Україні. - К.:ВЕРСО-04 $-2010 .-60$ c.

[15] Официальный сайт [Электронный ресурс]. - Режим доступа: http://w1.c1.rada. gov.ua/pls/zweb2/webproc4_1?pf3511=49269 
[16] Про державну підтримку сільського господарства України ( Відомості Верховної Ради України (ВВР), 2004, N 49, ст.527

[17]Проект Закона “О продовольственной безопасности Украины”.http://www.unian.net.

[18]Проект указа Президента Украины «Об основах обеспечения продовольственной безопасности Украины» http://minprom.ua/digest/142488.html

[19] Прохоров Б.Б. Общественное здоровье и экономика / Б.Б. Прохоров [и др.].- М.: МАКС Пресс, 2007. - 292 с. Официальный сайт [Электронный ресурс]. - Режим доступа: http://www.ukrstat.gov.ua/

[20] Римська Декларація про всесвітню продовольчу безпеку і План дій Всесвітньої зустрічі на вищому рівні з проблем продовольства, Рим,13 листопада 1996 p. [Электронний ресурс] / Продовольча і сільськогосподарська організація Об’єднаних Націй. Режим доступу: http:// www.rau.su/observer/N3-4_97/019.htm.

[21] Тутельян В.А, Разумов А.Н.,. Вялков А.И, Михайлов В.И., Москаленко К.А., Одинец А.Г., Сбежнева В.Г., Сергеев В.Н. Научные основы здорового питания:- М.: Издательский дом «Панорама», 2010.-816 с.

[22] Устав (конституция) Всемирной организации здравоохранения (НьюЙорк, 22 июля 1946 года) http://www.doctorate.ru/ustav-vsemirnojorganizacii-zdravooxraneniya/

[23] Флоринская Ю.Ф. Качество жизни и здоровье населения. [Электронный ресурс]. - Режим доступа: https://bio.1 september.ru/article.php?ID=200400504

[24] Хорбаньчук Я.О., Юзвик А., Томасик Ц., Хорбаньчук К., Шиманская Е., Сивец Д. Функциональные продукты питания животного происхождения и их значение для здоровья людей / Птица и птицепродукты 2009. - №3 - С.15-17.

ENSURING FOOD SAFETY - HEALTHY NATION

Under the conditions of formation of social and market development is redefining established concepts in science, changing of existing judgments and issue of food security of the population becomes the task of food safety, rather than solving the food problem. The article deals with the essential difference of concepts such as food safety and food problem. Ensuring food safety defines a new approach to public health, first of all as a vital economical resource of society. Health of the population gets not only the status of social value, but also helps to ensure the country's national security.

In the article there is studied the differentiation of health levels and highlighted the level of general-governmental health as a component of economic development of countries. Based on the fact that the problem of public health is defined in the context of economic development, was analyzed the health of the Ukrainian population during the period 19902013. Based on the concept of civilizational types of public health is defined type of health inherent in modern Ukraine. The main cause of death and disability in the population of Ukraine - chronic non-communicable diseases (CND). Medicine, putting the task to achieve health, deals with disease, i.e. an increases the amount of knowledge about the disease, diagnosis, treatment methods, and it does not pay sufficient attention to the ways of achieving health. That is why the modern system of fighting against CND is based on numerous concepts of health risk factors. Among the factors that shape human health, 
especially significant is the role of nutrition, which primarily depends on the quantity and quality of food.

Keywords: food security, public health, the types of public health, health risk factors.

\section{ZAPEWNIENIE BEZPIECZEŃSTWA ŻYWNOŚCIOWEGO - ZDROWIE}

\section{PUBLICZNE}

W warunkach rozwoju społecznego kluczowe jest przedefiniowanie ustalonych pojęć w nauce. Zmiana istniejących orzeczeń i kwestii bezpieczeństwa żywnościowego ludności staje się zadaniem bezpieczeństwa żywnościowego. Artykuł dotyczy istotnej różnicy pojęć, takich jak bezpieczeństwo żywnościowe i problem żywnościowy. Zapewnienie bezpieczeństwa żywności określa nowe podejście do zdrowia publicznego, przede wszystkim jako istotnego zasobu ekonomicznego społeczeństwa. Zdrowie publiczne ma nie tylko status wartości społecznej, ale także przyczynia się do zapewnienia bezpieczeństwa narodowego kraju. W artykule badano różnicowanie poziomu zdrowia i podkreślenono ogólny poziomu zdrowia populacji ukraińskiej w okresie 1990-2013. Główną przyczyną zgonów i niepełnosprawności w populacji Ukrainy - przewlekłe choroby niezakaźne (CND). Medycyna, stawiając zadanie osiągnięcia zdrowia, zajmuje się chorobą, czyli zwiększa ilość wiedzy na temat choroby, diagnostyki, metod leczenia. Nie zwraca się jednak wystarczająco dużo uwagi na sposoby osiągnięcia zdrowia. Dlatego też nowoczesny system walki z CND opiera się na licznych koncepcjach czynników ryzyka zdrowotnego. Wśród czynników, które kształtują ludzkie zdrowie, szczególnie istotna jest rola odżywiania, która zależy przede wszystkim od ilości i jakości żywności. Słowa kluczowe: bezpieczeństwo żywności, zdrowie publiczne, rodzaje zdrowia publicznego, czynniki ryzyka zdrowotnego.

DOI:10.7862/rz.2016.hss.43

Przesłano do redakcji: listopad 2015

Przyjęto do druku: wrzesień 2016 